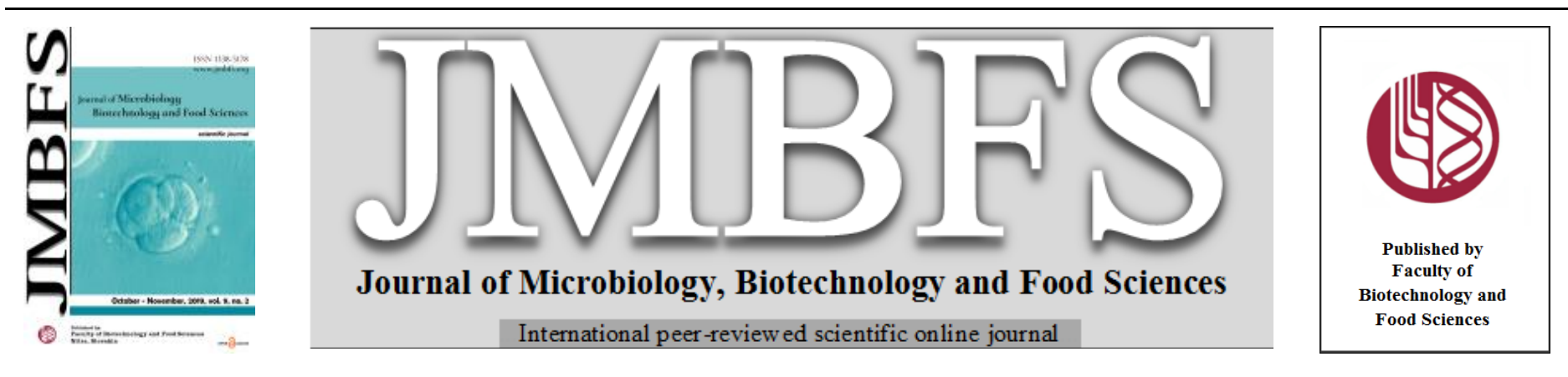

\title{
COPPER SULPHATE ELICITATION OF OPTIMIZED SUSPENSION CULTURE OF ANDROGRAPHIS PANICULATA NEES YIELDS UNPRECEDENTED LEVEL OF ANDROGRAPHOLIDE
}

\author{
Anilkumar A Dawande ${ }^{1}$, Sanjay Sahay*2 \\ Address(es): \\ ${ }^{1}$ Department of Botany, Govt. Science and Commerce College, Benazir, 462008 Bhopal, Madhya Pradesh, India. \\ ${ }^{2}$ Government postgraduate college, 465674 Biaora, Madhya Pradesh, India, Mob: 9425689386.
}

*Corresponding author: ss000@ rediffmail.com

doi: $10.15414 / j m b f s .2020 .9 .4 .688-694$

\section{ARTICLE INFO}

Received 12.3. 2019

Revised 31. 5. 2019

Accepted 27. 6. 2019

Published 3. 2. 2020

Regular article

oPEN $\partial_{\text {ACCESS }}$

\begin{abstract}
Concerted efforts have been made to push up andrographolide production through optimization of culture conditions, calli induction, cell growth and elicitation in cell suspension culture of Andrographis paniculata Nees. Optimum callus induction was obtained with cotyledon and hypocotyls of the plant on Skoog and Hilderbrandt (SH) medium containing $2.0 \mu \mathrm{g} / \mathrm{mL}$ 2,4- dichlorophenoxyacetic acid and $0.1 \mu \mathrm{g} / \mathrm{mL}$ 6-benzyl amino purine (BAP). Half MS medium containing $20 \mathrm{~g} / \mathrm{L}$ sucrose and $20 \mathrm{~h}$ photoperiod showed highest cells fresh weight (CFW) $(17.96 \pm 0.06 \mathrm{~g} / 50 \mathrm{~mL})$, growth index $(10.95 \pm 0.96)$ and andrographolide yield $(4.61 \pm 0.688 \mathrm{mg} / \mathrm{g} \mathrm{DCW})$. The addition of copper sulphate $(500 \mu \mathrm{M} / \mathrm{L})$, Methyl jasmonate $(25 \mathrm{mg} / \mathrm{L})$, Chitin $(500 \mathrm{mg} / \mathrm{L})$ or Fungal mycelium $(500 \mathrm{mg} / \mathrm{L})$ in separate experiments showed significant increase $(p=0.05)$ in bioproduction of andrographolide to the extent of $29.42 \pm 0.31 \mathrm{mg} / \mathrm{g} \mathrm{DCW}$, $13.13 \pm 0.11 \mathrm{mg} / \mathrm{g}$ DCW, $19.45 \pm 0.68 \mathrm{mg} / \mathrm{g}$ DCW and $13.629 \pm 1.12 \mathrm{mg} / \mathrm{g}$ DCW respectively, copper sulphate thus proved to be the most effective one. The study indicated that a holistic approach involving both culture conditions and elicitation could enhance the overall production of secondary metabolites (andrographolide) appreciably in this herb and possibly in other medicinal plants.
\end{abstract}

\section{INTRODUCTION}

Secondary metabolism in plants gives rise to a wide range of chemical compounds including coumarins, alkaloids, phenolics and terpenoids that may provide defense against pathogenic infections (Harborn,1982). These secondary metabolites form the basis for the development of new pharmaceutical drugs, herbicides, cosmetics and pesticides (Rodriguez-Concepscion and Boronat, 2002). One of the hindrances in the full use of potential of these plants is the low and variable yield of the bioactive substances in them. A concerted approach to address this problem is therefore of immense importance.

Andrographis paniculata belonging to Acanthaceae is an important medicinal plant possessing hepatoprotective and other pharmacological properties (Valiani et al., 2011). The plant is mainly known for its diterpene lactones such as andrographolide (Tang et al., 2012) that has been found to regulate a number of physiological functions in human being. It has been reported to regulate epidermal growth factor receptor and transferrin receptor trafficking in epidermoid carcinoma (A-431) cells (Tan et al., 2010) and interfere with binding of nuclear factor- $\kappa$ B to DNA in HL-60-derived neutrophilic cells (Hidalgo et al., 2005). It has also been known to possess several anti-inflammatory actions, including inhibition of intercellular adhesion molecule- 1 expression in monocyte activated by tumor necrosis factor- $\alpha$ (Habtemariam, 1998), suppression of nitric oxide synthetase (iNOS) expression in RAW2647 cells (Chiou et al., 2000), inhibition of microglial activation through inhibition of iNOS and cyclooxygenase-2 (COX-2) expression (Wang et al., 2004), and anticancer properties such as suppression of cancer cell proliferation, metastasis and angiogenesis (Lim et al., 2012). Andrographolide is thus a potential medicine to control asthma and other inflammatory diseases via inhibition of the Nuclear Factor- $\mathrm{\kappa B}$ Pathway (Bao et al., 2009) and may be applied in the treatment of cancer, autoimmune diseases (Hahn and Albersheim, 1978) and idiopathic pulmonary fibrosis (Zhu et al., 2013). The increased anticancer efficiency of andrographolide nanoparticle as found in MCF-7 cells and mice bearing Ehrlich ascites carcinoma (Roy et al., 2012) reiterate its importance as potential anticancer drug. Andrographolide nanoparticle has also been found to possess hepato-protective, anti- bacterial anti-malarial (anti-plasmodial) and anti-viral (Harborn, 1982; Valiani et al., 2011) activities and shown to protect against cigarette smoking induced chronic obstructive pulmonary disease (COPD) (Guan et al., 2013).
Despite immense usefulness, fuller utilization of A. paniculata has so far been hindered by some of its inherent weaknesses viz., too much variation in andrographolide-quantity found in different parts of plant and in plants with different geographical locations, too slow the rate of its vegetative propagation to meet the demand of pharmaceutical industries and too much variability among the seed derived progenies to rely on propagation through seeds (Martin, 2004) Attempts were also made to multiply A. paniculata through tissue culture, but callus developed on tissue culture media show low level of andrographolide despite elicitation (Zahir and Giri, 2015).

In view of growing importance of andrographolide and above hindrances both classical (Valdiani et al., 2013; Valdiani et al., 2014) and biotechnological (Vakil and Mendhulkar, 2012) approaches have been applied to enhance its production in the plant. Results from diallel crosses indicated the involvement of non-additive gene actions in increasing andrographolide content in A. paniculata, thus suggesting the usefulness of heterosis breeding as an approach to enhance biosynthesis of this bioactive substance (Valdiani et al., 2014). A natural bottleneck to this approach however comes from the finding that very low level of polymorphism occurs at least in the detected loci, indicating the presence of "fixed heterozygosity" in this plant (Valdiani et al., 2013). Therefore, the current approach has been to raise A. paniculata cell culture (Martin, 2004; Vakil and Mendhulkar, 2012; Gandi et al., 2012) and increase the quantity of andrographolide in the cell suspension culture by standardizing the media supplements (Sharmila et al., 2012) or using different abiotic and biotic inducers (Vakil and Mendhulkar, 2012; Gandi et al., 2012). There has however been hardly any emphasis on an integrated approach to optimize both the factors i.e. culture condition and elicitors concurrently in order to achieve maximum andrographolide production in the cell suspension culture.

The aim of the study was to optimize culture conditions to enhance calli induction and cells' growth-rate in suspension culture and then assess the role of important culture conditions and biotic and abiotic elicitors on the andrographolide production in the cotyledon-derived suspension culture since the leaves have been reported to contain maximum andrographolide (Valiani $\boldsymbol{e t}$ al., 2011). 


\section{MATERIAL AND METHODS}

\section{Materials}

The plant was collected from the forest area of Betul (India) and authenticated by Prof Kirti Jain, Government Postgraduate College, Benazir, Bhopal. MS, SH and B5 media, phytohormones, vitamins and metal ions (HiMedia Laboratories, Mumbai, India), androgapholide, chitin (Crab shell chitin) and methyl jasmonate (Sigma-Aldrich Chemicals Private Limited, Bangalore, India) were used in this study. Aspergillus niger (MTCC2733) was obtained from IMTECH, Chandigarh (India). Soxlet extraction system (model-msw-436) used was from MAC, New Delhi, India. Microcentrifuge used was from Remi, Mumbai, India. HPTLC (Linomet-V, ADC-II, Scanner-III, CAMAG, Switzerland) analysis was carried out at Biotechnology Application Center, Madhya Pradesh Council of Science and Technology, Bhopal.

\section{Sterilization of explants}

The explants were exposed to different surface sterilizing agents like mercuric chloride $(0.1 \%)$ and sodium hypo chloride $(1 \% \mathrm{w} / \mathrm{v})$ for $2-3 \mathrm{~min}$. The explant were washed thoroughly in running tap water for $1 \mathrm{~h}$ to remove all adhering dirt and phenols. The explants were then treated with dettol $(5 \mathrm{ml} / \mathrm{L})$ for $1 \mathrm{~min}$ followed by washing with water.

\section{Induction of callus}

The callus was initiated from four different types of explants viz. cotyledons, leaflet, epicotyl and hypocotyl of aseptically grown ten days old seedling. The explants were surface sterilized by treatment with mercuric chloride $(0.1 \% \mathrm{w} / \mathrm{v})$ for $5 \mathrm{~min}$ and transferred aseptically on to $\mathrm{SH}$ and Gamborg's (B5) media supplemented with different combinations of 2,4-D, Naphthalene acetic acid (NAA), Kinetin (KIN) and BAP (data not shown). The callus cultures were maintained on the same media and sub-cultured at 28 days interval.

Initiation and maintenance of suspension cultures

The fragile 8 weeks old callus (3g) grown on SH or MS media was aseptically transferred into the three selected growth media viz., MS , SH and B5 media (50 $\mathrm{mL})$ supplemented with 2, 4-D $(2.0 \mu \mathrm{g} / \mathrm{mL})+\mathrm{BAP}(0.5 \mu \mathrm{g} / \mathrm{mL})$ and Sucrose (3\% $\mathrm{w} / \mathrm{v}$ ) without agar in $250 \mathrm{~mL}$ Erlenmeyer flasks. The cultures were incubated in shaker incubator at $26 \pm 2^{\circ} \mathrm{C}$ and $120 \mathrm{rpm}$ and diffused light (500-600 lux). These suspension cultures were maintained by repeated sub-culturing at an interval of 21 days.

\section{Optimization of growth conditions for enhanced synthesis of andrographolide}

The effect of type of explants used, sugar concentration, growth regulators and photoperiod on the biomass accumulation and andrographolide concentration in the cell was studied. To begin with, the three media viz., MS, B5 and SH media were used. The best two media were then selected and the effect of differen factors was studied in such a way that at one time only one factor was considered and the best parameter selected was used to study the effect of another factor.

\section{Growth kinetics}

From the suspension cultures, the samples were withdrawn at the end of 5th, 10th, 20th, 30th and 40th day of incubation, filtered and weighed for determining growth-rate. This procedure was repeated thrice and the growth indices (GI) were calculated according to the following formula-

GI at day $\mathrm{N}=$ Tissue mass at day N-Tissue mass at start / Tissue mass at start

\section{Preparation of abiotic (Copper sulphate) elicitor}

Copper sulphate $\left(\mathrm{CuSO}_{4}, 5 \mathrm{H}_{2} \mathrm{O}\right)$ stock solutions were prepared by dissolving it in deionized water and passing it through $0.20 \mu \mathrm{m}$ syringe filter.

Preparation of biotic [fungal extract (FE), methyl jasmonate (MeJa) and chitin] elicitors

The fungal culture was raised in $1000 \mathrm{~mL}$ conical flasks containing $200 \mathrm{~mL}$ of potato dextrose broth for 10 days at $37^{\circ} \mathrm{C}$ and $100 \mathrm{rpm}$. Fully-grown mycelia with spores were homogenized and centrifuged at $8944 \mathrm{x}$ g. The supernatant was autoclaved for $20 \mathrm{~min}$ at $121^{\circ} \mathrm{C}$ and used as elicitor. MeJa stock solution $(62.5$ $\mathrm{mM}$ ) was prepared by transferring $21 \mu \mathrm{L} 95 \% \mathrm{MeJa}$ and $1479 \mu \mathrm{L}$ of ethanol to $1.5 \mathrm{~mL}$ microcentrifuge tube. The solution was filter-sterilized using a $0.20 \mu \mathrm{m}$ syringe filter. Various concentration of chitin solution was prepared by resuspending chitin from crab shells in deionized water and autoclaving it.

\section{Addition of precursors and elicitors}

The cell cultures of A. paniculata were grown in $250 \mathrm{~mL}$ Erlenmeyer flasks having $50 \mathrm{~mL}$ of growth medium. Different concentrations of elicitors viz., copper sulphate $(100 \mu \mathrm{M}-500 \mu \mathrm{M} / \mathrm{L})$, MeJa $(5-25 \mathrm{mg} / \mathrm{L})$ and chitin $(100-500$ $\mathrm{mg} / \mathrm{L})$ and, FE $(100-500 \mathrm{mg} / \mathrm{L})$ were added on the $16^{\text {th }}$ day to the cultures (stationary phase). The culture was allowed to various period of growth ranging from $12 \mathrm{~h}$ to $96 \mathrm{~h}$ following the addition of elicitor to standardize the induction period required for maximum metabolite accumulation. After harvesting the cultures, media and cells were separated and the fresh and dry weights were determined. Dry weights were determined after drying the cells at $60^{\circ} \mathrm{C}$ in a hot air oven until a constant weight was obtained. The biomass was expressed in grams Cell Dry Weight per liter (g/L CDW) (Kim et al., 2011). The medium filtrate was used for the estimation of andrographolide from A. paniculata.

\section{Analysis of andrographolide}

The cells were harvested and washed twice with deionised water and dried at $60^{\circ} \mathrm{C}$ to constant weight. The dry cell biomass was powdered and extracted in methanol in soxlet extraction system using $100 \mathrm{~mL}$ methanol applying standard method for 120 minutes $\left(2 \mathrm{cycles} / \mathrm{h}\right.$ at $\left.55^{\circ} \mathrm{C}\right)$. The extract was filtered and dried in air to remove solvent. The residue was then dissolved in HPLC-grade methanol $(1 \mathrm{~mL})$, filter sterilized and subjected to HPTLC analysis. Standard andrographolide was prepared by diluting $10 \mathrm{mg}$ of it with $100 \mathrm{~mL}$ of methanol to give a concentration of $100 \mu \mathrm{g} / \mathrm{mL}, 10$ $\mu \mathrm{L}$ of it was used in TLC. The andrographolide was calculated as $\mathrm{mg} / \mathrm{g}$ dry cell weight $(\mathrm{mg} / \mathrm{g} \mathrm{DCW})($ Dawande and Sahay, 2014).

\section{Statistical analysis}

Except otherwise stated, each experiment consisted of three replications with five culture vessels per replicate $(\mathrm{n}=15)$. The analysis of variance was performed on a completely randomized design with three main effects (types of calli, treatment and basal media) for callus induction or two main effects (sucrose concentration and basal media or photoperiod and basal media) for leaflet derived suspension culture or single effect (treatment) for elicitation of secondary metabolites by different elicitors. Significance of difference between the means of treatments of a particular parameter was estimated using the least significance difference (LSD) test at 5\% level of probability. The data as to the amount of andrographolide during standardizing the culture conditions, were expressed in terms of mean $(n=15) \pm$ standard error.

\section{RESULTS}

\section{Callus induction}

The callus initiation was observed after 10 days and grown to optimal level by three weeks as shown by different explants, but the rate of induction was different. Of various growth conditions tested for induction and growth of calli, the addition of $3 \%$ of sucrose was found to have profound effect (data not shown). Among different combinations of auxins and cytokinins that were tested with $\mathrm{B} 5$ and $\mathrm{SH}$ media, the highest callus induction $(93.33 \pm 1.66 \%)$ was shown by cotyledon explants on SH medium at 2, 4-D $(2.0 \mu \mathrm{g} / \mathrm{mL})$ and BAP $(0.1 \mu \mathrm{g} / \mathrm{mL})$ followed by leaflet explants $(83.33 \pm 2.89 \%)$ on SH at $2,4-\mathrm{D}(1.0 \mu \mathrm{g} / \mathrm{mL})$. Likewise, on SH medium, hypocotyl $(88.33 \pm 3.33 \%)$ and epicotyl $(83.33 \pm 1.67 \%)$ explants were found to form high number of calli when fortified with 2,4-D $(2 \mu \mathrm{g} / \mathrm{mL})+$ Kinetin $(0.5 \mu \mathrm{g} / \mathrm{mL})$ and 2 , 4-D $(2.0 \mu \mathrm{g} / \mathrm{mL})+$ BAP $(0.5 \mu \mathrm{g} / \mathrm{mL})$ respectively. Overall, the cotyledon explant was found to yield significantly the highest $(p=$ $0.05)$ calli induction $(93.33 \pm 1.66 \%)$ and that on SH medium supplemented with 2, 4-D $(2.0 \mu \mathrm{g} / \mathrm{mL})$ and BAP $(0.1 \mu \mathrm{g} / \mathrm{mL})$ while the same explants showed significantly the highest $(p=0.05)$ calli induction $(86.00 \pm 1.66 \%)$ on B5 medium supplemented with 2, 4-D $(1.5 \mu \mathrm{g} / \mathrm{mL})$.

As to the quality of calli, various growth media and combination of growth regulators had profound effect. Both B5 and SH medium supplemented with various cytokinins and auxins in combination gave a distinguishable greenish colour. Only SH +2 , 4-D $(2.0 \mu \mathrm{g} / \mathrm{mL})+\mathrm{KIN}(0.5 \mu \mathrm{g} / \mathrm{mL})$ gave brownish green colour to the callus developed from cotyledon. In both SH and B5 media, 2, 4-D alone produced compact callus from cotyledons but when 2, 4-D was applied with BAP and KIN friable calli were obtained in most cases. Some characteristics calli grown in response to various media composition and combinations of growth regulators are given in Fig.1. 

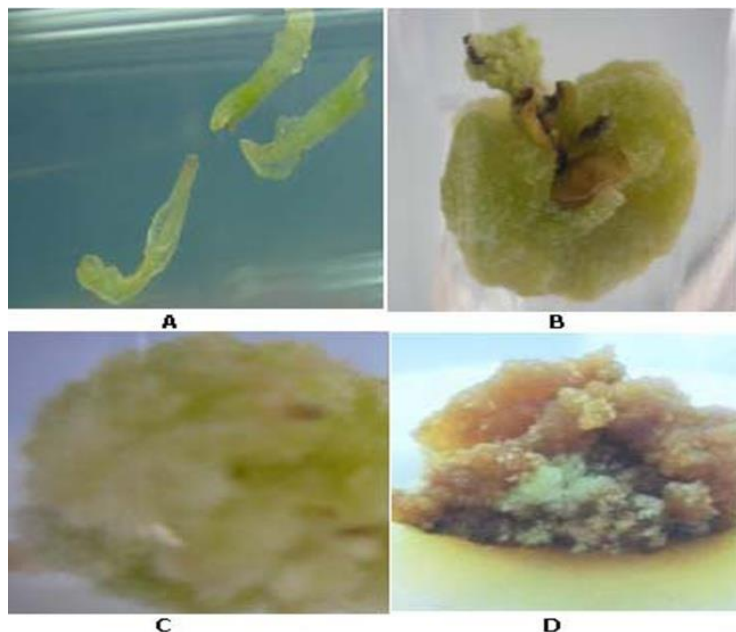

Figure $1 \mathrm{~A}$. Initiation of callusing at lower surface of hypocotyls on $\mathrm{B} 5+2,4-\mathrm{D}$ $2.0 \mu \mathrm{g} / \mathrm{mL}+\mathrm{BAP}, 0.5 \mu \mathrm{g} / \mathrm{mL}+$ sucrose, $30 \mathrm{~g} / \mathrm{L}$, B. Callus from cotyledon on B5 with 2,4-D, $2.0 \mu \mathrm{g} / \mathrm{mL}$; BAP, $0.5 \mu \mathrm{g} / \mathrm{mL}$; sucrose, $30 \mathrm{~g} / \mathrm{L}$, C. Callus from hypocotyls on SH without growth regulators and D. Callus from epicotyls on $\mathrm{SH}$ with 2,4-D, $2.0 \mu \mathrm{g} / \mathrm{mL} ; \mathrm{KIN}, 0.5 \mu \mathrm{g} / \mathrm{mL}$.

\section{HPTLC analysis of Andrographolide}

The combination of chloroform and methanol was found to be suitable solvent yielding optimum migration (mean $\mathrm{Rf}=0.59$ ) and resolution of andrographolide with its lambda $\max (\lambda$-max) value $231 \mathrm{~nm}$. Linearity of andrographolide was in the range of $100-600 \mathrm{ng} / \mathrm{L}$ with a calibration co-efficient of 0.99951 . The limit of detection and quantification was found to be $30 \mathrm{ng}$ and 100ng respectively (Dawande and Sahay, 2014) (Fig.2).

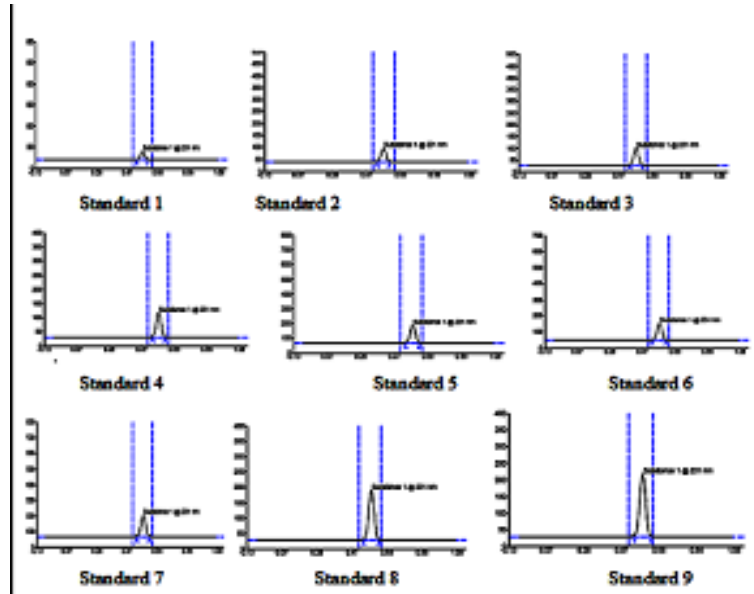

A. Peaks of standard andrographolide for HPTLC analysis

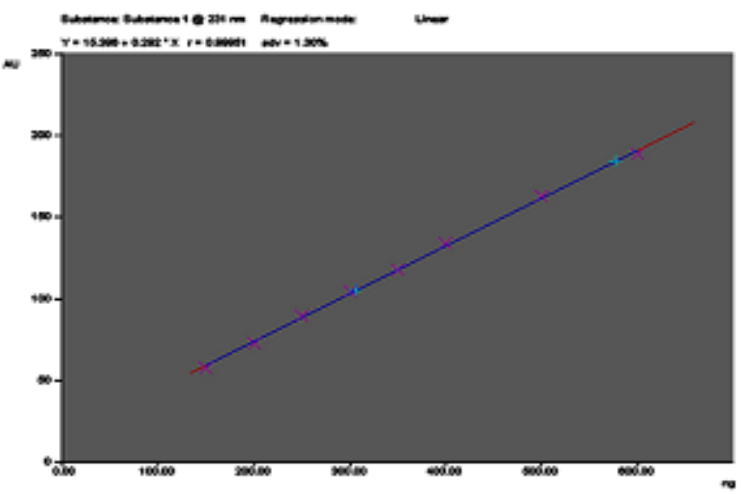

B. Calibration Curve of standard andrographolide for HPTLC analysis

Figure 2 Phytochemical analysis. A. HPTLC spectrogram of andrographolide standard; B, standard curve; $\mathrm{C}$, andrographolide from callus

\section{Optimization of biomass production in Suspension culture}

Among the three media (MS, SH and B5) applied initially for the cell suspension culture, the best result was shown by MS medium. Further standardization revealed the combination of $1 / 2 \mathrm{MS}$ medium, $20 \mathrm{~h}$ photoperiod and $2 \%$ sucrose to be the best, yielding significantly $(p=0.05)$ the highest biomass weighing $2.03 \pm 0.23 * \mathrm{~g} / \mathrm{mL}(\mathrm{Tab} 1)$

Table 1 Influence of media type, photoperiod and sucrose concentration on biomass production ${ }^{\mathrm{a}}$ in terms of CFW (cell fresh weight) and CDW (cell dry weight) in cotyledon derived suspension culture of A. paniculata.

\begin{tabular}{|c|c|c|c|c|c|c|c|}
\hline \multirow[t]{2}{*}{ Medium } & \multirow[t]{2}{*}{ Photoperiod (h) } & \multirow[t]{2}{*}{ Sucrose $(\mathrm{g} / \mathrm{L})$} & \multicolumn{2}{|c|}{$\begin{array}{c}\text { Gain in CFW } \\
(\mathrm{g} / 50 \mathrm{~mL})\end{array}$} & \multirow[t]{2}{*}{$\begin{array}{c}\text { Gain in CDW } \\
(\mathrm{g} / 50 \mathrm{~mL})\end{array}$} & \multirow[t]{2}{*}{ G I } & \multirow[t]{2}{*}{$\begin{array}{c}\text { LSD at } \\
5 \% \text { level }\end{array}$} \\
\hline & & & IW & FW & & & \\
\hline$\overline{\mathrm{MS}}$ & 00 & 20 & $1.98 \pm 0.08$ & $3.96 \pm 0.40$ & $0.33 \pm 0.01$ & $0.51 \pm 0.14$ & 0.674 \\
\hline MS & 16 & 20 & $2.09 \pm 0.05$ & $5.37 \pm 0.06$ & $0.45 \pm 0.12$ & $1.28 \pm 0.71$ & 0.674 \\
\hline MS & 20 & 20 & $2.03 \pm 0.04$ & $14.05 \pm 0.37$ & $1.17 \pm 0.10^{\mathrm{b}}$ & $7.70 \pm 0.15$ & 0.674 \\
\hline MS & 24 & 20 & $2.02 \pm 0.06$ & $4.26 \pm 0.02$ & $0.35 \pm 0.08$ & $0.67 \pm 0.53$ & 0.674 \\
\hline $1 / 2 \mathrm{MS}$ & 00 & 20 & $2.03 \pm 0.06$ & $4.35 \pm 0.31$ & $0.36 \pm 0.03$ & $0.70 \pm 0.22$ & 0.674 \\
\hline $1 / 2 \mathrm{MS}$ & 16 & 20 & $2.06 \pm 0.05$ & $6.33 \pm 0.02$ & $0.53 \pm 0.52^{b}$ & $2.03 \pm 0.23$ & 0.928 \\
\hline $1 / 2 \mathrm{MS}$ & 20 & 5 & $2.32 \pm 0.13$ & $6.80 \pm 0.26$ & $0.52 \pm 0.03$ & $1.53 \pm 0.35$ & 0.15 \\
\hline $1 / 2 \mathrm{MS}$ & 20 & 10 & $2.08 \pm 0.12$ & $9.13 \pm 0.10$ & $0.70 \pm 0.03^{b}$ & $3.91 \pm 0.18$ & 0.15 \\
\hline $1 / 2 \mathrm{MS}$ & 20 & 20 & $2.01 \pm 0.06$ & $17.96 \pm 0.06$ & $1.49 \pm 0.10^{\mathrm{b}}$ & $10.95 \pm 0.96$ & 0.928 \\
\hline $1 / 2 \mathrm{MS}$ & 20 & 30 & $2.10 \pm 0.10$ & $13.08 \pm 0.12$ & $1.20 \pm 0.10^{\mathrm{b}}$ & $6.46 \pm 0.41$ & 0.15 \\
\hline $1 / 2 \mathrm{MS}$ & 24 & 20 & $1.97 \pm 0.08$ & $3.93 \pm 0.05$ & $0.32 \pm 0.05$ & $0.51 \pm 0.34$ & 0.928 \\
\hline $\mathrm{SH}$ & 00 & 20 & $2.02 \pm 0.01$ & $4.04 \pm 0.14$ & $0.33 \pm 0.02$ & $0.47 \pm 0.13$ & 1.07 \\
\hline $\mathrm{SH}$ & 16 & 20 & $2.01 \pm 0.02$ & $6.89 \pm 0.60$ & $0.57 \pm 0.01$ & $2.60 \pm 0.16$ & 1.07 \\
\hline $\mathrm{SH}$ & 20 & 20 & $2.09 \pm 0.09$ & $12.12 \pm 0.08$ & $1.01 \pm 0.08^{\mathrm{b}}$ & $5.88 \pm 0.48$ & 1.07 \\
\hline $\mathrm{SH}$ & 24 & 20 & $1.95 \pm 0.05$ & $4.05 \pm 0.21$ & $0.33 \pm 0.02^{\mathrm{b}}$ & $0.66 \pm 0.19$ & 1.07 \\
\hline
\end{tabular}

${ }^{\mathrm{a}}$ The values represent the cell mass at day 16 post inoculation (mean \pm SE).b The data are significant $(p=0.05)$

\section{Optimization of andrographolide production in suspension culture}

The combination of culture conditions viz., $2 \%$ sucrose and $20 \mathrm{~h}$ photoperiod was found to be the optimum which in combination with either of the three medium yielded the highest production of andrographolide $(\sim 4.60 \mathrm{mg} / \mathrm{g} \mathrm{DCW})$
(Tab 2). The impact of medium on the yield of andrographolide was found to be negligible. 
Table 2 Effect of various factors on growth of cells and biosynthesis of andrographoide

\begin{tabular}{|c|c|c|c|c|}
\hline Media used & $\begin{array}{c}\text { Sucrose conc } \\
(\mathrm{g} / \mathrm{L})\end{array}$ & $\begin{array}{l}\text { Photoperiod } \\
\text { (h) }\end{array}$ & $\begin{array}{c}\mathrm{CDW}^{\mathrm{a}} \\
(\mathrm{g} / 50 \mathrm{~mL})\end{array}$ & $\begin{array}{c}\text { Andrographoloid }^{\mathrm{b}} \\
(\mathrm{mg} / \mathrm{g} \text { CDW })\end{array}$ \\
\hline B5 & 20 & 20 & $0.40 \pm 0.01$ & $4.59 \pm 0.459$ \\
\hline \multirow[t]{4}{*}{ SH } & 16 & 20 & $0.76 \pm 0.05$ & $4.60 \pm 0.621$ \\
\hline & & 16 & $0.57 \pm 0.01$ & $4.59 \pm 0.492$ \\
\hline & & 20 & $1.01 \pm 0.08$ & $4.59 \pm 0.555$ \\
\hline & 30 & 20 & $1.19 \pm 0.07$ & $4.60 \pm 0.562$ \\
\hline \multirow[t]{2}{*}{ MS } & 16 & 20 & $0.81 \pm 0.12$ & $4.59 \pm 0.87$ \\
\hline & & 20 & $1.17 \pm 0.10$ & $4.60 \pm 0.462$ \\
\hline \multirow[t]{5}{*}{$1 / 2 \mathrm{MS}$} & 16 & 20 & $1.22 \pm 0.06$ & $4.60 \pm 0.562$ \\
\hline & 20 & 0 & $0.36 \pm 0.03$ & $4.58 \pm 0.422$ \\
\hline & & 16 & $0.53 \pm 0.52$ & $4.60 \pm 0.459$ \\
\hline & & 20 & $1.49 \pm 0.10$ & $4.61 \pm 0.688$ \\
\hline & 30 & 20 & $1.20 \pm 0.10$ & $4.59 \pm 0.558$ \\
\hline
\end{tabular}

${ }^{\mathrm{a}}$ Average cell biomass (mean $\left.\pm \mathrm{SE} ; \mathrm{n}=15\right) ;{ }^{\mathrm{b}}$ Average cell biomass at day 16 post inoculation (mean $\pm \mathrm{SE} ; \mathrm{n}=15$ )

\section{Abiotic elicitation of andrographolide in suspension culture}

The addition of abiotic elicitor Copper sulphate at the concentrations of $100 \mu \mathrm{M}$, $200 \mu \mathrm{M}, 300 \mu \mathrm{M}, 400 \mu \mathrm{M}$ and $500 \mu \mathrm{M}$ was found to increase the andrographolide content $(\mathrm{mg} / \mathrm{g}$ DCW) significantly $(p=0.05)$ to $6.06 \pm 0.08(\sim 1.3$ fold), $10.10 \pm 0.12$ ( 2.18 fold), $12.98 \pm 0.14$ ( 2.81 fold), $14.58 \pm 0.36$ (3.18 fold) and $29.42 \pm 0.31$ (4.21fold) respectively over the control culture (4.61 \pm $0.688 \mathrm{mg} / \mathrm{g} \mathrm{DCW}$ ). Further increase of elicitor concentration to $600 \mu \mathrm{M}$ resulted in reduction of andrographolide production (Fig. 3A, Fig. 4A). The culture without elicitor gave significantly lower value of andrographolide production (4.620 mg/gm).

Since the observed $\mathrm{F}$ value 654.115 was much higher than that of tabular $\mathrm{F}$ value hence the effect of the treatment was significant (Tab 3). The correlation coefficient $(r=0.842)$ also indicated significant correlation $(p>0.05)$ between various concentrations of copper sulphate and andrographolide production.

\section{Biotic elicitation of andrographolide in suspension culture}

MeJa supplementation at the concentrations of $5 \mathrm{mg} / \mathrm{L}, 10 \mathrm{mg} / \mathrm{L}, 15 \mathrm{mg} / \mathrm{L}, 20$ $\mathrm{mg} / \mathrm{L}$ and $25 \mathrm{mg} / \mathrm{L}$ to the suspension cultures was found to have both positive and negative impact on andrographolide production; positive at low concentration (5$10 \mathrm{mg} / \mathrm{L})$ and negative at higher concentration (15-25 mg/L) (Fig. 3B, Fig. 4B) The elicitor concentrations of $5 \mathrm{mg} / \mathrm{L}$ and $10 \mathrm{mg} / \mathrm{L}$ were found to cause significant enhancement $(p=0.05)$ of biosynthesis of andrographolide yielding $4.949 \pm 0.06 \mathrm{mg} / \mathrm{g}(\sim 1.07$ fold $)$ and $13.13 \pm 0.11 \mathrm{mg} / \mathrm{g}$ DCW ( 2.84 fold $)$ respectively over the control cultures $(4.61 \pm 0.688 \mathrm{mg} / \mathrm{g} \mathrm{DCW})$.

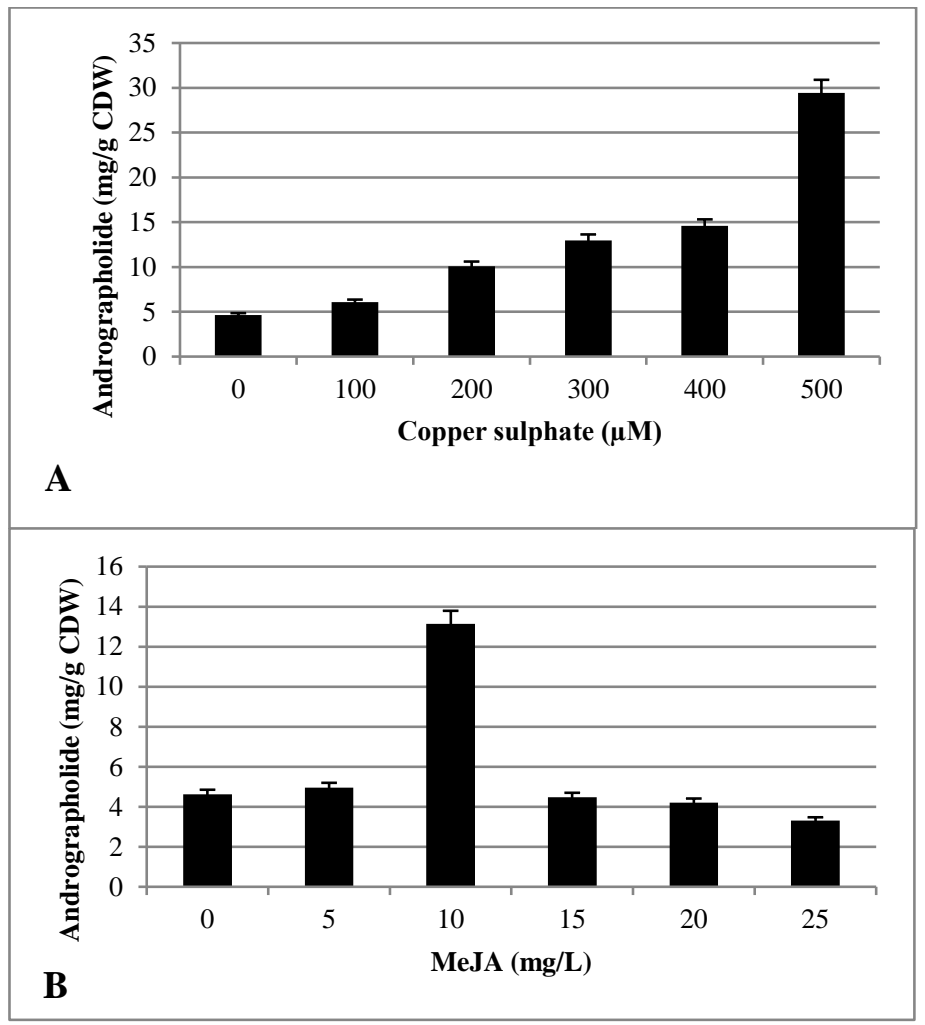

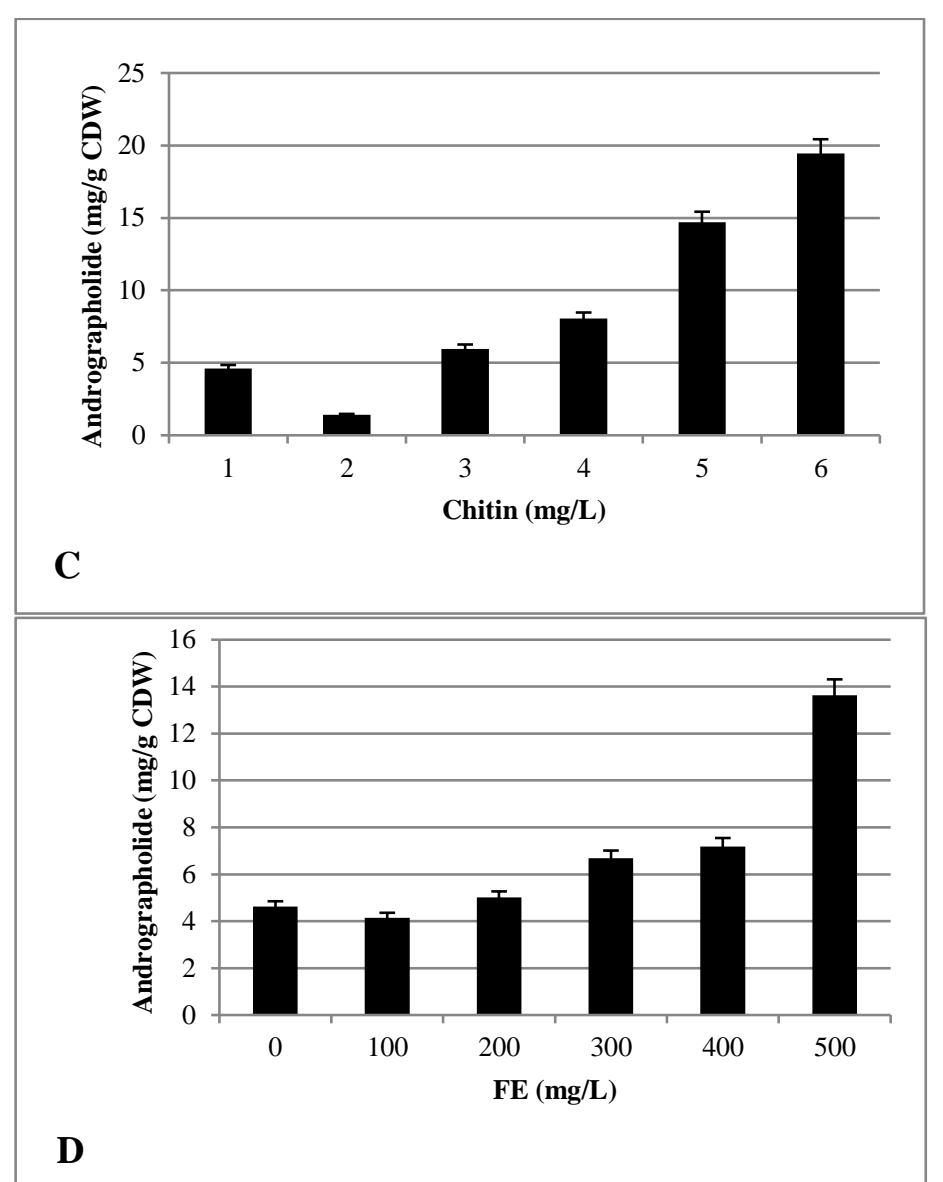

Figure 3 Effect of A. copper sulphate B. MeJa C. chitin and D. FE on andrographolide synthesis in A. paniculata cell suspension culture. 

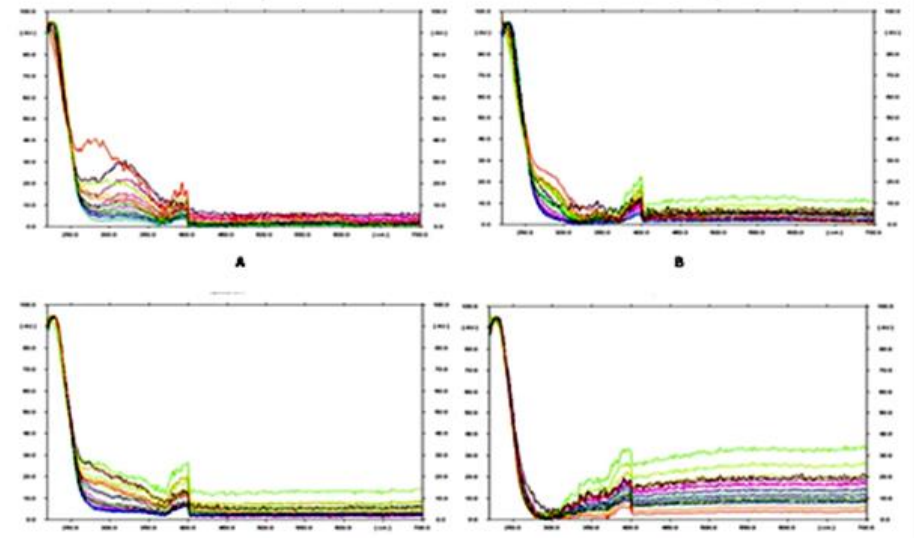

o
Figure 4 HPTLC spectra of andrographolide on all tracks after elicitation with A. Copper sulphate, B. MeJA, C. Chitin and D. Fungal mycelium on fifth days of elicitation.

Addition of Chitin in higher concentration (200-500 mg/L) showed significant increase $(p=0.05)$ in andrographolide content ranging from $\sim 1.29$ fold $(5.96 \pm 0.04 \mathrm{mg} / \mathrm{g} \mathrm{DCW})$ to $\sim 4.21$ fold $(19.45 \pm 0.68 \mathrm{mg} / \mathrm{g} \mathrm{DCW})$ over the control cultures $(4.61 \pm 0.688 \mathrm{mg} / \mathrm{g}$ DCW) (Fig. 3C, Fig. 4C).

The FE used as elicitor affected the growth of A. paniculata Nees cell suspension culture only slightly that too at higher concentrations only. Thus the highest production of andrographolide $(13.629 \pm 1.12 \mathrm{mg} / \mathrm{L} \mathrm{DCW})$ was found with an elicitor concentration of $500 \mathrm{mg} / \mathrm{L}$. The lower concentration of FE (100-200 $\mathrm{mg} / \mathrm{L}$ ) showed rather negative to no effect (Fig. 3D, Fig. 4D).

Statistical analysis on the effect of various biotic elicitors on andrographolide production showed observed $\mathrm{F}$ values much higher than the tabular $\mathrm{F}$ values at $5 \%$ level of significance (Tab 3). Therefore, the treatments were significant in case of all the three elicitors $(p>0.05)$.

Table 3 ANOVA for the effect of elicitors (Chitin, Methyl jasmonate (MeJa), Fungal mycelium (FE) and $\mathrm{CuSO}_{4}$ ) on the production of andrographolide in suspension cultures produced from A. paniculata explants.

\begin{tabular}{|c|c|c|c|c|c|}
\hline Source of variation & Degree of freedom & & ed F valu & arious eli & tions \\
\hline Replications & 2 & 2.89 & 4.11 & 21.0 & 5.92 \\
\hline Treatments & 5 & $289.43 *$ & $203.43 *$ & $161.04 *$ & $654.11 *$ \\
\hline Errors & 10 & - & & - & \\
\hline
\end{tabular}

* Significant at $\mathrm{p}<0.05$ as determined by $\mathrm{F}$

\section{DISCUSSION}

Of the two media viz. SH and B5 media used for calli induction, SH medium was proved to be better as reported earlier with respect to Eucalyptus camaldulensis (Prakash and Gurumurthi, 2010). The finding however does not support an earlier report that claimed MS medium in combination with lower concentration of 2,4-D and Kinetin as the best condition for the highest callus yield (Sharma and Jha, 2012). The reason for this difference seems to be the authors' missing chance to test other two media i.e. SH and B5 media. The explants yielding highest calli was cotyledon, a similar finding in case of $A$. paniculata was also reported earlier (Sharmila et al., 2013). Similar results were also obtained in case of other plants viz., Dioscorea balcanica (Katrina et al., 1998) and Trigonella foenum-graecum (Brain and Williams, 1983). As far as suitability of explants for accumulation of bioactive substance is concerned, the leaf calli were also found to be the most suitable starting material. Earlier, leaves were also reported to be the best explants for accumulation of high saponin and diosgenin in Trigonella foenum-graecum and Dioscorea galeottiana respectively (Brain and Williams, 1983; Roja et al., 1999).

In the next level, optimization was carried out with respect to andrographolide production in the suspension culture without elicitation. A parallel relation between optimum conditions for biomass production and for androgrpholide biosynthesis was observed. The tuned $1 / 2$ MS medium with $2 \%$ sucrose and $20 \mathrm{~h}$ photoperiod do seem to be optimum conditions for andrographolide biosynthesis. Thus, when compared to earlier data, the highest yield obtained by optimizing growth conditions upto this stage was almost three times more than that reported earlier $(1.58 \mathrm{mg} / \mathrm{g} \mathrm{DCW}$ ) without elicitation (Vakil and Mendhulkar, 2012). The results signify the importance of optimization of growth conditions as the first important step to enhance the yield of the bioactive substance.

Elicitation has been a very common strategy to enhance production of bioactive substances in plant cell factory including the production of andrographolide both in tissue culture (Zahir and Giri, 2015) or suspension culture. Using $\mathrm{CuSO}_{4}$ as abiotic elicitor, the optimum elicitation in terms of both the overall yield (29.42 $\pm 0.31 \mathrm{mg} / \mathrm{g} \mathrm{DCW})$ and yield-enhancement vis-a-vis control culture (4.21 fold) achieved was significantly high over previous ones $(2.42 \pm 0.08 \mathrm{mg} / \mathrm{g}$ DCW and 1.58 fold respectively) (Valdiani et al., 2013). The enhancement when compared to earlier optimized yield without elicitation $(1.58 \mathrm{mg} / \mathrm{g} \mathrm{DCW}$ ) (Vakil and Mendhulkar, 2012), turns out to be 18.6 fold, which is considerable. The result thus suggests a lower quantity $(0.5 \mathrm{mM})$ of abiotic stress $\left(\mathrm{CuSO}_{4}\right)$ to be the highly effective as an elicitor in andrographolide expression. This is also to be noted that with these combination of conditions (growth and elicitation) the increased andrographolide accumulation was obtained after 5-days of elicitation. This is in contrast with the earlier finding where $24 \mathrm{~h}$ was found to be optimum period for maximum accumulation of this bioactive substance in response to various elicitors, beyond which there was a decline in its accumulation (Vakil and Mendhulkar, 2012). It thus seems, that optimization of various conditions prior to elicitation delays the decline phase and thereby enhances the overall yield too. Copper sulphate has been reported to activate signaling pathways thereby enhancing production of secondary metabolites including andrographolide (Vakil and Mendhulkar, 2012). In basidiomycete fungus Pycnoporus sanguineus, $\mathrm{Cu}^{2+}$ elicitation has been reported to be associated with the expression of the enzymes involved in terpenoid backbone biosynthesis pathway and various terpene.
MeJa has also been an elicitor of choice in case of andrographolide bioproduction and applied in case of both tissue culture (Zahir and Giri, 2015) and suspension culture (Bhuvneswari et al., 2012). Using the concerted approach and with the elicitor concentrations of $5 \mathrm{mg} / \mathrm{L}$ and $10 \mathrm{mg} / \mathrm{L}$, a moderately higher yield of andrographolide equal to $4.949 \pm 0.06 \mathrm{mg} / \mathrm{g}$ and $13.13 \pm 0.11 \mathrm{mg} / \mathrm{g}$ DCW over the control cultures $(4.61 \pm 0.688 \mathrm{mg} / \mathrm{g} \mathrm{DCW})$ respectively has been achieved. A 3-fold enhancement of andrographolide production with this elicitor was also reported in tissue culture (Zahir and Giri, 2015) although a higher elicitation (5.25-fold) with lower concentration $(5 \mu \mathrm{M})$ of MeJA in suspension culture has also been reported (Sharmila et al., 2015) under different growth conditions. When compared to the base level of its production under standardized growth conditions (Vakil and Mendhulkar, 2012), the present level of production with growth standardization plus MeJa elicitation shows an overall 8.3-fold enhancement which is substantial and ratifies our assumption that growth optimization prior to elicitation exerts an additive effect on the accumulation of andrographolide in the plant cell. MeJa has also been shown to enhance the production of taxol and its analogues (Yukimune et al., 1996). At the molecular level, it has been found to initiates de novo transcription of genes, such as phenylalanine ammonialyase (involved in chemical defense in plants) and also intracellular cascades that begins with interaction of an elicitor molecule with the plant cell surface and results, ultimately, in the accumulation of secondary compounds (Gundilach et al., 1992) including anthocyanin (Franceschi and Grimes, 1991). In A. paniculata, MeJa elicited andrographolide accumulation has been found to be correlated with the expression level of regulatory genes (hmgs, hmgr, dxs, dxr, isph and ggps) of mevalonic acid (MVA) and 2-C-methyl-D-erythritol-4-phosphate (MEP) pathways thereby indicating the involvement of MeJA in andrographolide biosynthesis by inducing the transcription of its biosynthetic pathways genes (Sharmila et al., 2015).

The FE used as elicitor was found to enhance bioproduction of andrographolide as a function of the concentrations, although at lower concentration (100-200 $\mathrm{mg} / \mathrm{L}$ ) it showed negative to no effect (Fig. 3D). Earlier, significan elicitation with yeast culture filtrate (Vakil and Mendhulkar, 2012), an optimum 6.94-fold elicitation $(0.132 \mathrm{mg} / \mathrm{g})$ with the fungus Aspergillus niger and 6.23 -fold elicitation $(0.81 \mathrm{mg} / \mathrm{g})$ with the fungus Penicillium expansum of andrographolide in the cell suspension culture of A. paniculata (Gandi et al., 2012) have been reported. The overall, yield reported however was much lower $(0.132 \mathrm{mg} / \mathrm{g})$ than the present one $(13.629 \mathrm{mg} / \mathrm{g})$ reiterating a cumulative effect of growth optimization and elicitation in expression of andrographolide.

Treatment with biotic or abiotic elicitors has been a useful strategy to enhance secondary metabolite production in plant tissue and cell cultures. The induction mechanism of elicitors is generally regarded as inducing the expression of defense-related genes and activating defense-related secondary metabolic pathways (Sharmila et al., 2012; Valdiani et al., 2014). The optimum concentration of biotic elicitors (chitin and FE) was found to be $500 \mathrm{mg} / \mathrm{L}$ in enhancing the production of andrographolide while the optimum time (duration) for triggering the elicitation in 16 days older culture was found to be five days. These results supported the earlier findings with respect to Salvia miltiorrhiza (Valdiani et al., 2014) and A. panicculata (Gandi et al., 2012) but contradicted that of other (Vakil and Mendhulkar, 2012) who found one day incubation with elicitor to be optimum for andrographolide production by A. paniculata. This deviation seems to be attributable to the difference in media and growth conditions 
used during the two experiments. The finding thus again highlights the importance of optimization of growth condition in addition to elicitation to enhance biosysnthesis of secondary metabolite. Although standard media are available for culturing various plant tissue/cell, all of them require a fine tuning with respect to growth regulators when a new plant is selected for its tissue culture. For enhanced production of plant bioactive substances, elicitation is now becoming a common practice. It is however a common practice that elicitation is standardized adopting an earlier reported culture protocol only. The culture protocols themselves at most of the times happen to be growth-oriented and not yield-oriented. Hardly, standardization of both culture condition to obtain higher tissue/cells yield and elicitation to get optimum yield of bioactive substance is carried out concurrently. Plants are known to produce secondary metabolites in response to various stresses including presence of heavy metals and invading pathogens. These responses have been evolved as part of genetics of the hosts supported by fine network of signal transduction system. Generally, small molecules such as components of pathogen's cell wall (e.g., chitin, xyloglucans, chitosan, glucan and oligogalacturonide) may serve as signal molecules or elicitors. The fact indeed has prompted to use such elicitors to enhance the production of selected secondary metabolites in cultured plant tissue (Vakil and Mendhulkar, 2012; Gandi et al., 2012).

Molecular studies have revealed involvement of transient $\mathrm{Ca}^{2+}$ influx (Zimmermann et al., 1997), mitogen-activated protein kinase (MAPK) and Gprotein activation (Droillard $\boldsymbol{e t}$ al., 2000), changes in protein phosphorylation pattern and protein kinase activation (Felix et al., 1997), acidification of cytoplasm caused by $\mathrm{H}^{+}$-ATPase inactivation (Armero and Tena, 2001), production of ROS such as superoxide anion and $\mathrm{H}_{2} \mathrm{O}_{2}$ (Apostol and Heinstein, 1989) etc during elicitation. It will be interesting to study the molecular pathway related to the newly identified elicitor $\mathrm{CuSO}_{4}$ triggering transcription pathway and consequent transcription (transcriptomics) and translation of proteins that catalyze the biosynthetic pathway of andrographolide production (metabolomics) (Gossens et al., 2003). An earlier such study in A. paniculata in connection with andrographolide accumulation in response to MeJa elicitation revealed the upregulation of some regulators connected with MEV and MEP pathways (Sharmila et al., 2015), and thus paved the way for metabolic engineering to enhance andrographolide biosynthesis. Nonetheless, more studies are needed 11 explore cross talk between various pathways involved in the elicitations an relative importance of various regulators so as to enable ones to select mo potent one for use in metabolic engineering.

\section{CONCLUSIONS}

The two prong strategy to enhance andrographolide bioproduction in $A$ paniculata has thus been found effective. Standardization of growth conditions during suspension culture itself has been found to lead to three fold enhancement of metabolite production (cf $1.58 \mathrm{mg} / \mathrm{g}$ DCW, Gandi et al. 2012). The optimized culture could be elicited with a simple compound, $\mathrm{CuSO}_{4}$ to cause the unprecedented level of yield of andrographolide. When the relative effectiveness of the abiotic and abiotic elicitors used in the present work is examined, abiotic $\left(\mathrm{CuSO}_{4}\right)$ one is certainly proved to be better one inducing andrographolide biosynthesis to an unprecedented level $(29.42 \pm 0.31 \mathrm{mg} / \mathrm{g}$ DCW). Molecular analysis of this result may be of interest that may help in metabolic engineering towards further enhancing of bioproduction of andrographolide in the plant. In view of growing concern about side effects of the synthetic medicines and negative impact of synthetic processes on the environment, demand for natura medicines will continue to grow. This will cause pressure on the natural sources and pose serious threat to already dwindling biodiversity. Tissue culture thus holds the key to fulfill the demand for natural products without causing threat to environment and biodiversity. These results will provide impetus to similar works in other plants.

Conflict of Interest: The authors declare that there is no conflict of interest of any type.

Compliance of Ethics Requirements: This article does not contain any studies with human or animal subjects.

Acknowledgement: The authors express their sincere gratitude to Madhya Pradesh Council of Science \& Technology, Bhopal for HPTLC analysis of andrographlide.

\section{REFERENCES}

Apostol, 1., Heinstein, P.F. \& Low P.S. (1989) Rapid stimulation of an oxidative burst during elicitation of cultured plant cells: Role in Defense and Signal $\begin{array}{llll}\text { Transduction. Plant } & \text { Physiology, } & 109, & 116\end{array}$ https://doi.org/10.1104/pp.90.1.109

Armero, J. \& Tena, M. (2001) Possible role of plasma membrane $\mathrm{H}^{+}$-ATPase in the elicitation of phytoalexin and related isoflavone root secretion in chickpea (Cicer arietinum L.) seedlings. Plant Science, 161, 791-798. http://doi.org/10.1016/S0168-9452(01)00472-1

Bao, Z., Guan, S., Cheng, C., Wu, S., Wong, S.H., Kemeny, D.M., Leung, B.P. \& Wong, W.S.(2009) A novel antiinflammatory role for andrographolide in asthma via inhibition of the nuclear factor-kappaB pathway. American Journal of Respiration and Critical Care Medicine,179, 657-665. http://doi.org/10.1164/rccm.200809-15160C

Bhuvaneswari, C., Kiranmayee, R., Suryakala, G. \& Archana, G. (2012) Abiotic elicitation of gymnemic acid in the suspension cultures of Gymnema sylvestre. World Journal of Microbiology and Biotechnology, 28, 741-747. http://doi.org/10.1007/s11274-011-0870-8

Brain, K.R. \& Williams, M.H. (1983) Evidence for an alternative route from sterol to sapogenin in suspension cultures from Trigonella foenumgraecum. Plant cell reports, 2(1), 7-10. http://doi.org/10.1007/BF00269224

Chiou, W.F., Chen, C.F. \& Lin, J.J. (2000) Mechanisms of suppression of inducible nitric oxide synthase (iNOS) expression in RAW 264.7 cells by andrographolide. British Journal of Pharmacolgy, 129, 1553-1560. http://doi.org/10.1038/sj.bjp.0703191

Dawande, A.K. \& Sahay, S. (2014) Development and validation of HPTLC method for estimation of andrographolide in crude extract of callus tissue. Inventi Impact Pharma, 5.

Droillard, M.J., Thibivilliers, S., Cazale, A.C., Barbier, B.H. \& Lauriere, C. (2000) Protein kinases induced by osmotic stresses and elicitor molecules in tobacco cell suspensions: two crossroad MAP kinases and one osmoregulationspecific protein kinase. FEBS Letters, 74, 217-222. http://doi.org/10.1016/S00145793(00)01611-2

Felix, G., Grosskopf, D.G., Regenass, M. \& Boller, T. (1991) Rapid changes of protein phosphorylation are involved in transduction of the elicitor signal in plant cells. Proceeding of National Academy of Science USA, 88, 8831-8834. http://doi.org/10.1073/pnas.88.19.8831

Franceschi, V.R. \& Grimes, H.D. (1991) Induction of soybean vegetative storage proteins and anthocyanins by low-level atmospheric methyl jasmonate. Proceeding of National Academy of Science USA, 88, 67456749. https://doi.org/10.1073/pnas.88.15.6745

Gandi, S., Rao, K., Chodisetti, B. \& Giri, A. (2012) Elicitation of andrographolide in the suspension cultures of Andrographis paniculata. Applied Biochemistry and Biotechnolology, 168(7), 1729-1738. http://doi.org/10.1007/s12010-012-9892-4

Goossens, A., Hakkinen, S.T., Into Laakso I., Seppanen-Laakso, T., Biondi, S., De Sutter, V., Lammertyn, F., Nuutila, A.M., Söderlund, H., Zabeau, M., Inze, D. \& Oksman-Caldentey, K. (2003) A functional genomics approach toward the understanding of secondary metabolism in Plant cells. Proceeding of National Academy of Science USA, $100 \quad$ (14), 8595- 8600. http://doi.org/10.1073/pnas.1032967100

Guan, S.P., Tee, W., Ng, D.S., Chan, T.K., Peh, H.Y., Ho, W.E., Cheng, C., Mak, J.C. \& Wong, W.S. (2013) Andrographolide protects against cigarette smokeinduced oxidative lung injury via augmentation of Nrf2 activity. British Journal of Pharmacology, 168,1707-1718. http://doi.org/10.1111/bph.12054

Gundlach, H., Muller, M.J., Kutchan, T.M. \& Zenk, M.H. (1992) Jasmonic acid is a signal transducer in elicitor-induced plant cell culture. Proceeding of National Academy of Science USA, 89, 2389-2393. https://doi.org/10.1073/pnas.89.6.2389 Habtemariam, S. 1998. Andrographolide inhibits the tumour necrosis factoralpha-induced upregulation of ICAM-1 expression and endothelial-monocyte adhesion. Phytotherapy Research, 12, 37-40. http://doi.org/10.1002/(SICI)10991573(19980201)12:1:1<37::AID-PTR186>3.0.CO;2-N

Hahn, M.G. \& Albersheim, P. (1978) Host-Pathogen Interactions. Xiv. Isolation and partial characterization of an elicitor from yeast extract. Plant Physiology, 62 (1), 107-111.

Harborne, J.B. (1982) Phytochemical dictionary. In: Handbook of bioactive compounds from plants (2nd ed.). London: Taylor and Francis, 22-25.

Hidalgo, M.A., Romero, A., Figueroa, J., Cortes, P., Concha, I.I., Hancke, J.L. \& Burgos, R.A. (2005) Andrographolide interferes with binding of nuclear factor$\kappa \mathrm{B}$ to DNA in HL-60-derived neutrophilic cells. British Journal of Pharmacology, 144(5), 680-686. http://doi.org/10.1038/sj.bjp.0706105

Katrina, S.F., Dragljub, G.L.C., Nebojsa, M. \& Mihailo, R. (1998) Diosgenin phytosterols content in five callus lines of Dioscorea balcanica. Plant Science, 135, 63-67. http://doi.org/10.1016/s0168-9452(98)00036-3

Kim, H.J., Sung, M.K. \& Kim, J.S. (2011) Anti-inflammatory effects of glyceollins derived from soybean by elicitation with Aspergillus sojae. Inflammation Research, 60(10), 909-917. http://doi.org/10.1007/s00011-0110351-4

Lim, J.C.W., Chan, T.K., Ng, D.S., Sagineedu, S.R., Stanslas, J. \& Wong, W.F. (2012) Andrographolide and its analogues: versatile bioactive molecules for combating inflammation and cancer. Clinical and Experimental Pharmacology and Physiology, 39, 300-310. http://doi.org/10.1111/j.1440-1681.2011.05633.x Martin, K.P. (2004) Plant regeneration protocol of medicinally important Andrographis paniculata (Huvam. V.) Wallich Ex Nees.Via somatic embryogenesis. In vitro cell and Development Biology, 40(2), 204-209. https://doi.org/10.1079/IVP2003520

Prakash, M.G. \& Gurumurthi, K. (2010) Effects of type of explant and age, plant growth regulators and medium strength on somatic embryogenesis and plant regeneration in Eucalyptus camaldulensis. Plant Cell Tissue and Organ Culture (PCTOC),100(1),13-20. http://doi.org/10.1007/s11240-009-9611-1 
Rodriguez-Concepcion, M. \& Boronat, A. (2002) Elucidation of the methylerythritol phosphate pathway for isoprenoid biosynthesis in bacteria and plastids: A metabolic milestone achieved through genomics. Plant Physiology, 130,1079-1089. http://doi.org/10.1104/pp.007138

Rojas, R., Alba, J., Magan-plaza, I., Cruz, F. \& Ramos-Valdivia, A.C. (1999) Stimulated production of Diosgenin in Dioscorea galeottiana cell suspension cultures by abiotic and biotic factors. Biotechnology Letters, 21(10), 907-911. https://doi.org/10.1023/A:1005598623728

Roy, P., Das, S., Mondal, A., Chatterji, U.\& Mukherjee, A. (2012) Nanoparticle engineering enhances anticancer efficacy of andrographolide in MCF-7 cells and mice bearing EAC. Current Pharmaceutical Biotechnology, 13(15), 2669-2681. http://doi.org/10.2174/138920112804724855

Sharma, S.N. \& Jha, Z. (1998) Production of andrographolide and cell suspension cultures of Andrographis paniculata. Journal of cell and tissue Research, 12(3), 3423-2429.

Sharma, S.N., Jha, Z., Sinha, R.K. \& Geda, A.K. (2015) Jasmonate-induced biosynthesis of andrographolide in Andrographis paniculata. Physiology Plant, 153, 221-229. http://doi.org/10.1111/ppl.12252

Sharmila, R., Subburathinam, K.M. \& Sugumar, P. (2013) Effect of growth regulators on andrographolide production in callus cultures of Andrographis paniculata. Advanced BioTech, 12 (9), 17-20.

Tang, C., Liu, Y., Wang, B., Gu, G., Yang, L., Zheng, Y., Qian, H. \& Huang, W.S. (2012) Synthesis and biological evaluation of andrographolide derivatives as potent anti-HIV agents. Archiv der Pharmazie-Pharmaceutical and Medicinal Chemistry, 345, 647-656.

https://doi.org/10.1016/j.cclet.2011.01.015

Tan, Y., Chiow, K.H., Huang, D. \& Wong, S.H. (2010) Andrographolide regulates epidermal growth factor receptor and transferrin receptor trafficking in epidermoid carcinoma (A-431) cells. British Journal of Pharmacology, 159(7), 1497-1510. http://doi.org/10.1111/j.14765381.2009.00627.x

Vakil, M.M.A. \& Mendhulkar, V.D. (2012) Enhanced synthesis of andrographolide by Aspergillus niger and Penicillium expansum elicitors in cell suspension culture of Andrographis paniculata (Burm. f.) Nees. Botanical Studies, 54, 49-56. http://doi.org/10.1186/1999-3110-54-49

Valdiani, A., Javanmard, A., Talei, D., Tan, S.G., Nikzad, S., Kadir, M.A. \& Abdullah, S.N. (2013) Microsatellite-based evidences of genetic bottlenecks in the cryptic species "Andrographis paniculata Nees": a potential anticancer agent Molecular Biology Report, 40, 1775-1784. https://doi.org/10.1007/s11033-0122231-6

Valdiani, A., Talei, D., Tan, S.G., Kadir, M.A., Maziah, M., Rafii, M.Y. \& Sagineedu, S.R. (2014) A classical genetic solution to enhance the biosynthesis of anticancer phytochemicals in Andrographis paniculata Nees. PLoS ONE, 9(2), e87034. http://doi.org/2014;10.1371

Valiani, M., Zolfaghari, M., Nazemi, M., Pirhadi, M. \& Ebrahimian, S. (2011) The relationship between family planning methods, individual hygiene, and fertility with vaginal infections among the women referring to selected health centers in Isfahan city. Iran Journal of Nursing and Midwifery Research, 16, 8392.

Wang, T., Liu, B., Zhang, W., Wilson, B., Hong, J.S. (2004) Andrographolide reduces inflammation-mediated dopaminergic neurodegeneration in mesencephalic neuronglia cultures by inhibiting microglial activation. J Pharmacol Exp Ther, 308, 975-983. https://doi.org/10.1124/jpet.103.059683

Yukimune, Y., Tabata, H., Higuchi, Y. \& Hara, Y. (1996) Methyl jasmonate induced over production of paclitaxel and baccatin III in Taxus cell suspension cultures. Nature Biotechnology, 11, 129-1132. http://doi.org/10.1038/nbt09961129

Zaheer, M. \& Giri, C.C. (2015) Multiple shoot induction and jasmonic versus salicylic acid driven elicitation for enhanced andrographolide production in Andrographis paniculata, Plant Cell Tissue and Organ Culture (PCTOC), 122, 553-563. https://doi.org/10.1007/s11240-015-0787-2

Zimmermann, S., Nürnberger, T., Frachisse, J.M., Wirtz, W., Guern, J., Hedrich, R. \& Scheel D, (1997) Receptor-mediated activation of a plant $\mathrm{Ca}^{2+}$-permeable ion channel involved in pathogen defense. Proceeding of National Academy of Science USA, 94, 2751-2755.

https://doi.org/10.1073/pnas.94.6.2751

Zhu, T., Zhang, W., Xiao, M., Chen, H. \& Jin, H. (2013) Protective role of andrographolide in bleomycin-induced pulmonary fibrosis in mice. International Journal of Molecular Science 2013, 14, 23581-23596. http://doi.org/10.3390/ijms141223581 